\title{
Zablokowane ExSV czy pojedyncze pobudzenia nawrotne? Jeden zapis, dwie interpretacje
}

\author{
Non-conducted supraventricular beats or retrograde atrial activation? \\ One ECG strip, two interpretations
}

\author{
Michał Kałowski, Jan Ruta, Paweł Ptaszyński, Krzysztof Kaczmarek, Iwona Cygankiewicz \\ Klinika Elektrokardiologii Uniwersytetu Medycznego w Łodzi
}

\section{Streszczenie}

W artykule przedstawiono opis przypadku młodej pacjentki z wywiadem napadowych częstoskurczów nadkomorowych poddanej inwazyjnemu badaniu elektrofizjologicznemu i jednoczasowo ablacji drogi wolnej węzła przedsionkowo-komorowego. W 24-godzinnym monitorowaniu elektrokardiograficznym metodą Holtera, wykonanym dobę po zabiegu, okresowo obserwowano zapis, który, zdaniem autorów, można równoprawnie interpretować na dwa sposoby - jako przedwczesne pobudzenia przedsionkowe zablokowane lub wsteczną aktywację przedsionków.

Słowa kluczowe: przedwczesne pobudzenia nadkomorowe, wsteczna aktywacja przedsionków, ablacja

Folia Cardiologica 2015; 10, supl. C: 24-26

\section{Opis przypadku}

Pacjentka w wieku 35 lat, z wywiadem źle tolerowanego napadowego częstoskurczu nadkomorowego, została przyjęta do Kliniki Elektrokardiologii Uniwersytetu Medycznego w Łodzi z powodu nasilenia arytmii w 4. dobie po porodzie metodą cięcia cesarskiego. Wcześniej chora nie godziła się na wdrożenie leczenia farmakologicznego ani badanie elektrofizjologiczne (EPS, electrophysiologic study) z ewentualną ablacją. 19 sierpnia 2014 roku wykonano EPS - obserwowano samoistny nawrotny częstoskurcz z łącza przedsionkowo komorowego (AVNRT, atrio-ventricular node reentry tachycardia) o typie slow-slow i jednoczasowo podjęto próbę ablacji drogi wolnej prądem o częstotliwości radiowej (RF, radio frequency). Po aplikacjach obserwowano blok przedsionkowo-komorowy (AVB, atrioventricular block) I stopnia z odstępem PQ do 230 ms. W kontrolnym EPS nie wyzwalano arytmii, obserwowano jedynie pojedyncze pobudzenia nawrotne węzłowe. Niestety, kilka godzin po zabiegu oraz w kolejnej dobie ponownie obserwowano napady AVNRT. Do leczenia włączono metoprolol w dawce $75 \mathrm{mg} /$ dobę.

\section{4-godzinne monitorowanie elektrokardiograficzne}

W zapisie 24-godzinnej rejestracji elektrokardiograficznej (EKG) metodą Holtera w 1. dobie po zabiegu, w godzinach 15:00-18:30, 21:50-22:40, 00:10-02:50 oraz 03:45-06:00, dominował rytm zatokowy ze średnią częstością około 70/min. W pozostałych godzinach obserwowano napady częstoskurczu z wąskimi zespołami QRS o częstości do 160/min, trwające do 3,5 godziny. 0 godzinie 21:02 chorej podano adenozynę w dawce 12 mg, co spowodowało wystąpienie krótkiego epizodu całkowitego AVB z rytmem zastępczym o częstości 13-30/min i pauzami do 5,9 s (ryc. 1). W trakcie całego zapisu obserwowano AVB I stopnia ( $\mathrm{PQ}$ do maks. $230 \mathrm{~ms}$ ). Okresowo występował obraz, który - zdaniem autorów - można równoprawnie 
Okres: 24 godzin

Średnia częst.rytmu (p/min) 200

50 (p/min)/div

Kursor $=132 \mathrm{p} / \mathrm{min}$

\section{100 \\ 100
50}

Lefitulur

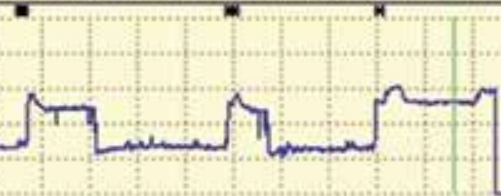

Rycina 1. Wykres trendu częstości akcji serca w trakcie 24-godzinnego monitorowania EKG metodą Holtera

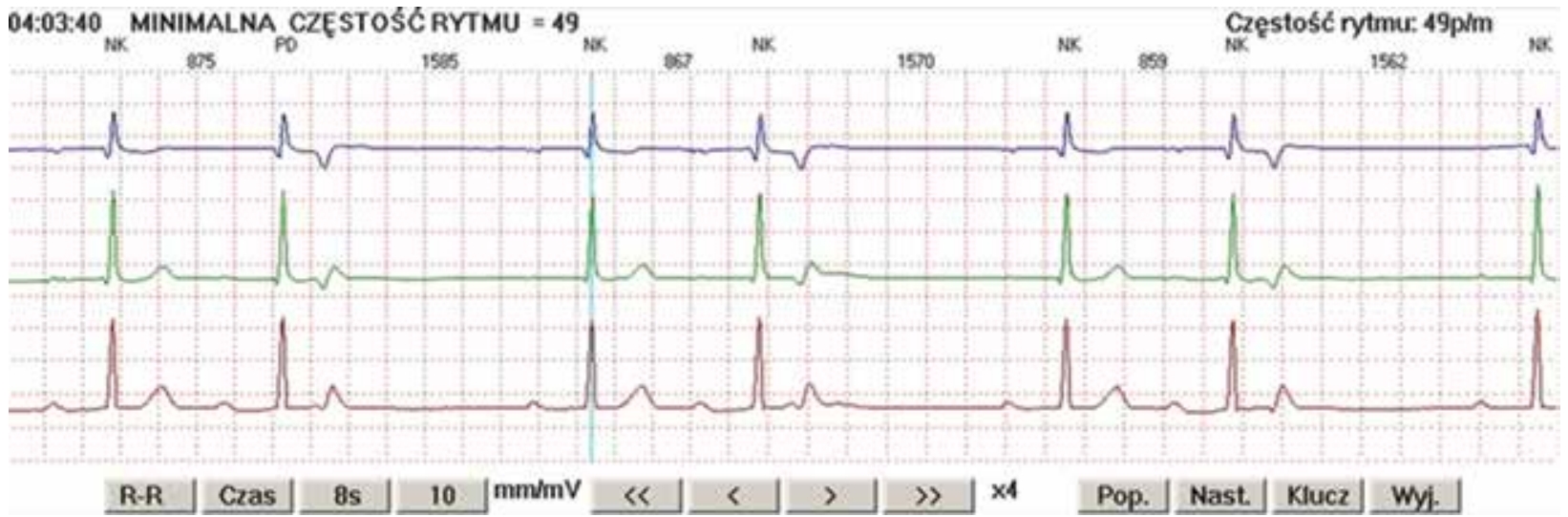

Rycina 2. Pojedyncze zablokowane pobudzenia nadkomorowe lub pojedyncze pobudzenia nawrotne

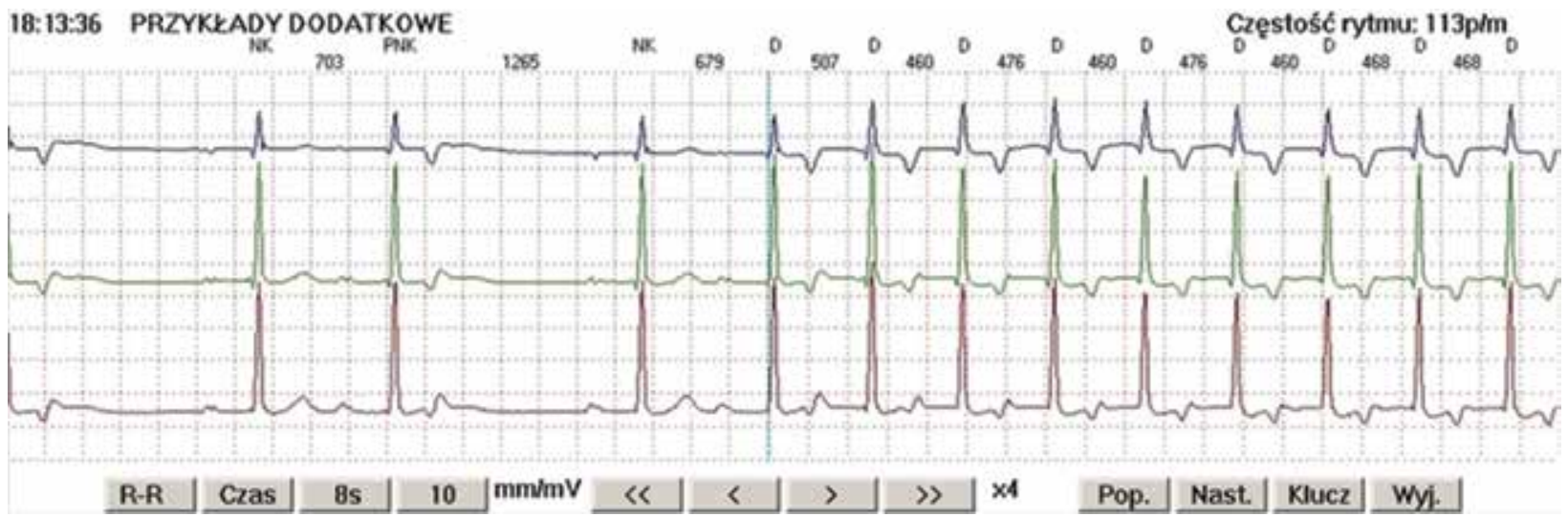

Rycina 3. Jednoogniskowy częstoskurcz przedsionkowy lub częstoskurcz w mechanizmie reentry

interpretować na dwa sposoby. Pierwsza z proponowanych interpretacji zakłada, że w zapisie obserwowano pojedyncze pobudzenia nadkomorowe (ExSV, [łac.] extrasystolia supraventricularis) układające się w zablokowaną bi- i trigeminię nadkomorową (ryc. 2). Jeden z kolejnych ExSV w układzie trigeminii (dotychczas zablokowanych) zainicjował jednokształtny częstoskurcz przedsionkowy (AT, atrial tachycardia) (ryc. 3). Według drugiej z możliwych interpretacji aktywacje przedsionków po zespołach QRS, wcześniej opisywane jako zablokowane ExSV, stanowią w istocie pojedyncze pobudzenia nawrotne (ryc. 2), a jeden z takich nawrotów staje się początkiem częstoskurczu w mechanizmie reentry (ryc. 3).

\section{Omówienie}

W „Wytycznych dotyczących stosowania rozpoznań elektrokardiograficznych" [1] można znaleźć dwa rozpoznania, których kryteria są w pełni spełnione i których można by użyć do opisu tego samego zjawiska. Są to 
„pobudzenia przedwczesne przedsionkowe zablokowane” oraz „wsteczna aktywacja przedsionków”. Biorąc pod uwage samą krzywą EKG, nie sposób zdecydować, które z nich powinno być zastosowane. Zbieżność odcinka ST-T z nałożonym załamkiem $\mathrm{P}$ w przypadku pojedynczych pobudzeń nawrotnych/zablokowanych ExSV oraz w trakcie częstoskurczu sugeruje, że w obu przypadkach mechanizm powstania załamka P jest taki sam. Obserwowany częstoskurcz jest zapoczątkowany przez załamek $P$ identyczny z załamkami P w trakcie częstoskurczu, co uprawdopodabnia diagnozę AT. Jedocześnie nie obserwowano charakterystycznej dla AT zmienności częstości załamka P (fazy przyspieszania, stabilizacji i zwalniania). Częstoskurcz został przerwany podaniem adenozyny, co nie wyklucza rozpoznania AT, jednak bardziej prawdopodobną czyni diagnozę częstoskurczu nawrotnego z udziałem węzła przedsionkowo-komorowego [2]. Długość odstępu RP, wynosząca w tym przypadku 180 ms, wyklucza rozpoznanie typowego AVNRT, a rozpoznaniem najbardziej prawdopodobnym czyni ortodromowe AVRT. Jedynie dzięki wiedzy zdobytej w trakcie EPS możemy postawić ostateczną diagnozę atypowego AVNRT o typie slow-slow i zinterpretować zjawisko widoczne na rycinie 2 jako pojedyncze pobudzenia nawrotne węzłowe. Prawdopodobnie wpływ na występowanie obserwowanych zjawisk miała przebyta przez chorą nieskuteczna ablacja RF i związany z zabiegiem obrzęk tkanek okołowęzłowych, skutkujący pogorszeniem przewodzenia drogą szybką (AVB I stopnia, niski punkt Wenckebacha), co sprzyjało przechodzeniu przewodzenia na droge wolną. Nie można także wykluczyć, że przewodzenie drogą szybką zostało całkowicie zablokowane, a w trakcie obserwacji odbywa się ono stale jedną z dróg wolnych (stąd AVB I stopnia), okresowo natomiast przechodzi na drugą z nich, dając nawrót węzłowy lub AVNRT.

\section{Podsumowanie}

Na zakończenie, w nawiązaniu do tematu przewodniego Maratonu EKG Kasprowisko 2015 - „EKG, nasze sukcesy, nasze porażki”, można przytoczyć ostateczny efekt leczenia pacjentki. Powtórzono ablację RF, uzyskując ustąpienie nawrotów arytmii w kilkumiesięcznej obserwacji. Ustąpiły także, obserwowane po pierwszym zabiegu, zaburzenia przewodzenia przedsionkowo-komorowego. To, co początkowo było porażką, ostatecznie udało się zakończyć sukcesem.

\section{Konflikt interesów}

Autorzy deklarują brak konfliktu interesów.

\section{Abstract}

This article presents a case of a young female patient with a history of paroxysmal supraventricular tachycardia subjected to electrophysiology study and an atrioventricular node slow pathway ablation. The 24-hour Holter ECG monitoring was performed the day after the procedure. According to the authors ECG recording can be equally interpreted in two ways - as blocked premature atrial beats or retrograde atrial activation.

Key words: supraventricular premature beats, retrograde atrial activation, ablation

Folia Cardiologica 2015; 10, supl. C: 24-26

\section{Piśmiennictwo}

1. Baranowski R., Wojciechowski D., Maciejewska M. i wsp. Zalecenia dotyczące stosowania rozpoznań elektrokardiograficznych. Kardiol. Pol. 2010; 68 (supl. IV): 1-56.
2. Zipes D.P., Issa Z.F., Miller J.M. i wsp. Arytmologia kliniczna i elektrofizjologia. Elsevier Urban \& Partner. Wrocław 2010 